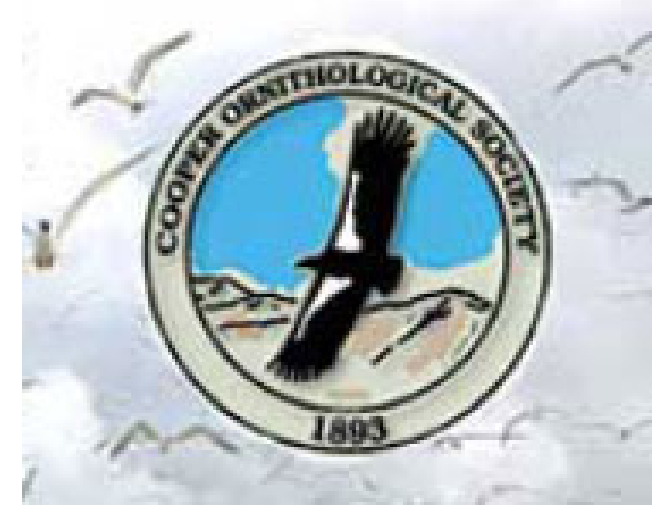

Survival, Emigration, and Winter Population Structure of Harlequin Ducks Author(s): Fred Cooke, Gregory J. Robertson, Cyndi M. Smith, R. Ian Goudie, W. Sean Boyd Reviewed work(s):

Source: The Condor, Vol. 102, No. 1 (Feb., 2000), pp. 137-144

Published by: University of California Press on behalf of the Cooper Ornithological Society

Stable URL: http://www.jstor.org/stable/1370414

Accessed: 23/04/2012 16:27

Your use of the JSTOR archive indicates your acceptance of the Terms \& Conditions of Use, available at http://www.jstor.org/page/info/about/policies/terms.jsp

JSTOR is a not-for-profit service that helps scholars, researchers, and students discover, use, and build upon a wide range of content in a trusted digital archive. We use information technology and tools to increase productivity and facilitate new forms of scholarship. For more information about JSTOR, please contact support@jstor.org. 


\title{
SURVIVAL, EMIGRATION, AND WINTER POPULATION STRUCTURE OF HARLEQUIN DUCKS ${ }^{1}$
}

\author{
Fred Cooke, Gregory J. Robertson ${ }^{2}$ and Cyndi M. SMith \\ Department of Biological Sciences, Simon Fraser University, Burnaby, British Columbia, V5A IS6, Canada, \\ e-mail:fcooke@sfu.ca \\ R. IAN GoudiE ${ }^{3}$ AND W. SEAN Boyd \\ Pacific Wildlife Research Centre, Canadian Wildlife Service, 5421 Robertson Road, Delta, British Columbia, \\ V4K 3N2, Canada
}

\begin{abstract}
A population of individually marked Harlequin Ducks (Histrionicus histrionicus) at White Rock, British Columbia, Canada was examined to measure the degree of population differentiation among birds which pair during the winter months. This required an understanding of the patterns of emigration among wintering sites in different segments of the population. Some juveniles arrived at the wintering grounds accompanied by their mothers, thus initially arriving into the same winter population as their parents. Young males were more likely than young females to disperse during the first two years of life. Adult males had higher local survival than adult females during the summer months, probably because of the greater mortality risks to nesting females. During the nonbreeding seasons, local survival was the same in both sexes. Paired males had a local survival of more than $90 \%$, suggesting both high survival and strong philopatry. Unpaired males had a lower local survival rate, suggesting they have higher mortality and/or emigration rates. Young females had the same local survival rate as adult females, suggesting that they did not disperse during the winter. These winter philopatry patterns are similar to the general pattern of breeding philopatry in waterfowl, with females showing stronger philopatry than males, and paired adults stronger philopatry than unpaired and young birds. The dispersal of young males makes local population differentiation unlikely in this species.
\end{abstract}

Key words: dispersal, Harlequin Duck, Histrionicus histrionicus, juveniles, movement, philopatry.

\section{INTRODUCTION}

The degree of population genetic differentiation found among populations of conspecific animals is a function of the amount of gene flow occurring among the segments of those populations (Rockwell and Barrowclough 1987). The degree of gene flow is related to the amount of dispersion that occurs between birth location and subsequent breeding location, or more specifically to the location where a mate is chosen. An understanding of population structure has both a genetic and an ecological component. Many animals show a high degree of natal philopatry (Greenwood 1980, Johnson and Gaines 1990), which results in a strong likelihood of animals choosing a mate with a similar genetic compo-

\footnotetext{
${ }^{1}$ Received 23 March 1999. Accepted 21 October 1999.

${ }^{2}$ Present address: Canadian Wildlife Service, 6 Bruce Street, Mount Pearl, Newfoundland, A1N 4T3, Canada.

${ }^{3}$ Present address: 17 Waterford Bridge Road, St. John's, Newfoundland, A1E 1C5, Canada.
}

sition to themselves. Over time this could lead to genetic sub-structuring of the population into a variety of geographically isolated subpopulations and even to speciation. When animals move widely between their natal location and where they choose their mates, the population is likely to show panmixia, and less population differentiation. A better understanding of population structure requires an integration of genetic and ecological studies. Even populations which lack genetic differentiation, may show population structure through their patterns of philopatry and dispersion which may have important implications in terms of conservation of isolated populations.

The ecological study of natal and breeding philopatry is valuable for examining population structure when, as in most birds, pair formation occurs at the location where breeding occurs. In waterfowl, however, pair formation often occurs away from the breeding area, often during winter (Anderson et al. 1992). In this case, birds from several different breeding areas may be associated in a single wintering location (Syroech- 
kovski et al. 1994) and pair formation may involve two birds from different breeding locations. Under these circumstances, gene flow among different breeding areas is widespread (Cooke et al. 1975, Cronin et al. 1996). For this reason, northern hemisphere ducks show little phenotypic variation throughout large geographic areas, as witnessed by the paucity of subspecies (Ankney et al. 1986).

Birds which pair away from their breeding grounds would be expected to show population genetic differentiation only if (1) young winter at the same location as their parents, (2) there is no dispersal between wintering sites of either pre-breeding or breeding birds (Robertson and Cooke 1999), and (3) these patterns have occurred over a considerable period of time. Many migratory ducks form annual pair bonds (Rohwer and Anderson 1988), which would be expected from the weak winter philopatry shown by most ducks (Fedynich et al. 1989, Robertson and Cooke 1999). But long term pair bonds have been documented in sea ducks (Bengtson 1972, Savard 1985), and there is evidence of strong natal, breeding, and winter philopatry in this group (Dow and Fredga 1983, Savard and Eadie 1989).

We chose the Harlequin Duck (Histrionicus histrionicus) for an examination of population structure from an ecological viewpoint, for several reasons: (1) genetic analyses of population structure in this species suggest genetic differentiation at least on the broad scale (Brown 1998, K. Scribner, unpubl. data), but ecological verification for the differentiation through studies of the movements of individual birds is lacking, (2) philopatry to both breeding and wintering grounds has been documented (Bengtson 1972, Breault and Savard, in press), and (3) there is evidence of long term pair bonds (Gowans et al. 1997, Robertson et al. 1998b, Smith et al., in press), making local population differentiation in the wintering grounds a possibility. Although long term pair bonds are not a requirement for population differentiation, they certainly facilitate it.

The objectives of this paper are to examine age and sex-specific survival and emigration rates of a wintering population of Harlequin Ducks to (1) determine how young birds are recruited into this population, (2) detect stages of the life cycle when males and females leave the population, either through death or emigration,
(3) understand the roles of survival and dispersal on local population demography, and (4) determine whether there is the potential for genetic differentiation given the patterns of emigration and recruitment detected.

\section{METHODS}

This study examined a population of $100-150$ Harlequin Ducks that molt and winter along a 5 $\mathrm{km}$ stretch of rocky shoreline between White Rock (WR) and Crescent Beach in Boundary Bay, British Columbia, Canada. Most birds reside at this location throughout the year, except when they depart to breed. First birds arrive from the breeding grounds in June and most birds leave in April or May. Most sightings occur during the early fall and again in spring, when birds are most likely to haul out of the water. Harlequin Ducks were captured annually during the wing molt in July and early August (males) and September (females) from 1994 to 1998. Captured birds were sexed by plumage or, in the case of juveniles, by cloacal examination. Birds were aged by assessing the length of the Bursa of Fabricius; birds with bursa exceeding $20 \mathrm{~mm}$ in length were classified as yearlings (SY), birds with a bursa of $5-10 \mathrm{~mm}$ as 2-year olds (TY), and those with little or no sign of a bursa were classified as adults (ATY) (Mather and Esler 1999). Juveniles (HY), which were very rare in our sample, were identified by their plumage, presence of a large bursa $(>20 \mathrm{~mm})$, and by their ability to fly. All birds were marked with unique alphanumeric, colored leg bands to allow individual recognition; these bands could be read when the birds hauled out onto rocks. In 1997 and 1998, a few additional birds were marked with nasal disks, consisting of small plastic shapes of different colors attached by a short length of monofilament. The study area was monitored from July 1994 to November 1998 at least once a month and much more frequently during the molting period and in spring prior to the departure of birds to the breeding grounds. We occasionally monitored a second study location in Boundary Bay, $20 \mathrm{~km}$ away at Point Roberts (PR), Washington, USA. If we recorded birds at that location, we included them in our data because these observations provide evidence that birds were still alive and in the general area of Boundary Bay. Birds were viewed with $20-60 \times$ telescopes, and the loca- 
tion, molt state, and pair status of all individually marked birds were recorded.

Juvenile birds are very similar to adult females, however there are some subtle differences; juveniles had a finely vermiculated plumage on the breast, mottled yellow and gray feet, and, occasionally, notched tail feathers could be seen. Juveniles then underwent a partial body molt and entered the first alternate plumage (Witherby et al. 1943), at which time immature males were distinguishable from older males, but immature females could not be distinguished from older females. The transition from juvenile to first alternate plumage occurred as early as late September (Smith et al. 1998).

We defined the population of study as the birds that were present in the study area during the molting period; for males from mid-June until mid-September, and for females from midJuly until late-October (Cooke et al. 1997, Robertson et al. 1997b). Apart from the annual departure to the breeding grounds, which occurred in late April until late May (Breault and Savard 1991, Robertson et al. 1997a, in press), most birds were present at the study site from the time of their arrival prior to molt until spring departure. Few exceptions to this pattern include: (1) a small number of birds (usually $<5$ ) that remained at WR throughout the summer as nonbreeders; these were usually yearlings, (2) birds that left the area during the coldest months of the winter but returned prior to spring departure (Robertson et al. 1997a), (3) birds that molted in another location but wintered at WR (Robertson et al., in press); this resulted in an influx of unbanded birds to WR after molt (these birds were not included in our sample), and (4) some birds that molted at WR but wintered elsewhere. These latter individuals were included in our sample and were used to estimate annual survival because they returned each year to molt, however, they were not used in analyses to determine which season (summer or winter) individuals disappeared, nor could we determine their pairing status.

\section{DATA ANALYSES}

Only birds captured and/or sighted at least twice during the year were considered reliable observations. Due to the high resighting effort, the probability of resighting individuals that were alive and in the study area was $100 \%$ during the molt (July-September) and in the spring
(March-May) (Robertson et al., in press). If an individual was not seen on these occasions, we inferred that the individual died/emigrated during the preceding interval. Program MARK (White and Burnham 1999) was used to obtain point estimates and confidence intervals for age and sex-specific local survival rates. Local (or apparent) survival rates are the combined probability of an individual surviving and returning to a study area (Lebreton et al. 1992). MARK also was used to estimate local survival rates of adults after first capture and for subsequent captures. The age-structured data set was analyzed by building a set of models where age classes were sequentially pooled in all possible combinations. The most parsimonious model (lowest Akaike Information Criterion, AIC) was determined, and only point estimates from the most parsimonious model are presented. For specific tests, we obtained point estimates for local survival rates that we a priori determined to be important and used $Z$-tests to assess significance (Pollock et al. 1990). We did not assess heterogeneity in our data with program RELEASE, as we had expectations that a fully time dependent model (Cormack-Jolly-Seber, CJS) would fit the data very poorly due to the age structure in our data.

The probability of return may be related to a bird's pair status. Because of the male biased sex-ratio, there were always several unpaired adult males in our population, but we had no evidence of unpaired adult females (Robertson et al. 1998a). There were also several birds whose pairing status was unknown to us. To compare local survival of paired males with the rest of the males, we combined data on unknown and unpaired males because of inevitable bias in our data, if we had not done so. Most paired males can be scored for pair status soon after they and their mates return from their breeding streams. However unpaired birds can only be determined by their failure to obtain a mate by May of the following year, thus allowing only 3 months during which survival can be measured. Any unpaired bird dying or disappearing prior to that date must be classified as of unknown pair status. It is necessary to combine data in this way to minimize the bias, but this probably results in a few paired males being included in the sample of unknown birds. This does not change the conclusions from the analysis.

All means are presented as $\pm \mathrm{SE}$, rates are 
TABLE 1. Period when Harlequin Ducks were last seen that did not return to White Rock, British Columbia in the subsequent year, defined as the interval between one molting period (July-August) and the next. No annual differences were detected in the probabilities of when birds were last seen, so data were pooled across years $(P>0.05)$. Proportions (95\% profile likelihood intervals) are presented below numbers of ducks.

\begin{tabular}{|c|c|c|c|c|}
\hline & \multirow[b]{2}{*}{$\begin{array}{l}\text { Number } \\
\text { present } \\
\text { in year } i\end{array}$} & \multirow[b]{2}{*}{$\begin{array}{c}\text { Number } \\
\text { absent } \\
\text { in year } i+1\end{array}$} & \multicolumn{2}{|c|}{ Period when last seen in year $i$} \\
\hline & & & $\begin{array}{c}\text { Fall }^{\mathrm{a}} \\
\text { (winter loss) }\end{array}$ & $\begin{array}{c}\text { Spring } \\
\text { (summer loss) }\end{array}$ \\
\hline Males & 177 & $\begin{array}{c}37 \\
0.209(0.155-0.275)\end{array}$ & $\frac{22}{0.124(0.083-0.182)}$ & $\begin{array}{c}15 \\
0.085(0.051-0.136)\end{array}$ \\
\hline Females & 143 & $\begin{array}{c}38 \\
0.266(0.200-0.344)\end{array}$ & $\begin{array}{c}14 \\
0.098(0.059-0.159)\end{array}$ & $\begin{array}{c}24 \\
0.168(0.115-0.238)\end{array}$ \\
\hline Total & 320 & $\begin{array}{c}75 \\
0.234(0.191-0.284)\end{array}$ & $0.112(0.082-0.152)$ & $\begin{array}{c}39 \\
0.122(0.090-0.163)\end{array}$ \\
\hline
\end{tabular}

Last seen between August and February.

b Last seen between March and May, calculated as the proportion alive at beginning of year.

presented as $\pm \mathrm{SE}$ (95\% profile likelihood interval) and a critical $P$ of 0.05 was used throughout.

\section{RESULTS}

Between 1994 and 1997, 150 birds were marked, 77 males and 73 females. We also include four birds originally banded while breeding in Alberta that molted at WR. The proportion of young ( $2 \mathrm{HY}, 4 \mathrm{SY}, 4 \mathrm{TY}$ ) males (10 of $77 ; 13.0 \%$ ) was lower than that of young ( $2 \mathrm{HY}$, $13 \mathrm{SY}, 13 \mathrm{TY})$ females $(28$ of $73 ; 38.4 \%)\left(G_{1}=\right.$ $12.7, P<0.01)$.

As many as eight juveniles were seen at the study site at one time from mid-August onwards. Birds in juvenile plumage often were seen in closely associating groups of two to six, usually with adult females nearby. Observations on 22 August 1997, strongly suggested that these juveniles were with their mothers. Five birds were seen diving and bringing items to the surface, and when they hauled out on a rock, were identified as four juveniles and a banded adult female (G4). These five birds acted as a group with the adult hen (G4) would lead the tightly grouped young. Soon after, this "family" of five was diving near another family consisting of a banded female (unknown code) and two juveniles. When an underwater Common Loon (Gavia immer) caused the two families to panic, the adult and one juvenile from the smaller family flew $100 \mathrm{~m}$, the remaining juvenile then associated with the larger family but was kept separate by the adult female G4 and after $60 \mathrm{sec}$ it flew off and joined its own family. Later the two families, both diving, merged and there was aggression by one of the adults.
No detectable difference was found between male disappearance in the fall and winter period and in the spring and early summer period $\left(\chi^{2}{ }_{1}\right.$ $=0.7, P>0.4)$, whereas almost twice as many females disappeared from the study area after the spring, relative to the fall and winter period $\left(\chi^{2}{ }_{1}=5.8, P<0.02\right)$ (Table 1$)$. The mortality/ emigration of the two sexes was not detectably different during the molt and winter periods $\left(\chi^{2}{ }_{1}\right.$ $=0.6, P>0.4)$, but was different during the summer $\left(\chi^{2}{ }_{1}=5.1, P<0.03\right)$. Overall, female annual mortality/emigration rates were not detectably different from males $\left(\chi^{2}{ }_{1}=1.4, P>\right.$ 0.2) (Table 1).

The best fitting (lowest AIC) model for agespecific local survival rates produced three estimates for males: first-year $(0.0)$, combined second and third year $(0.56 \pm 0.17 ; 95 \% \mathrm{CI}=$ $0.25-0.82)$, and adult (0.82 $\pm 0.03 ; 0.76-0.87)$, and one estimate for females: all age classes combined $(0.74 \pm 0.04 ; 0.66-0.80)$. A constant recapture rate of $0.98 \pm 0.01(0.94-0.99)$ was estimated by this model. The model was not very different from the next best model (ratio of AIC weight $=1.42$ ), so strong inferences about differences in survival rates could not be made. Young male (second and third year) local survival was marginally lower than adult male local survival $(Z=1.57, P=0.12)$. Adult male local survival tended to be higher than female local survival $(Z=1.75, P=0.08)$.

Local survival rates of adult males tended to be lower after their first year of capture $(0.75 \pm$ $0.05 ; 0.63-0.84)$ than in subsequent years $(0.86$ $\pm 0.04 ; 0.78-0.92)(Z=1.84, P=0.06)$. There was no detectable difference between these two groups for females (after first capture: $0.71 \pm$ 
0.07 ; $0.56-0.82$; subsequent years: $0.77 \pm 0.06$; $0.64-0.87)(Z=0.66, P>0.2)$.

Paired males had a significantly higher rate of return $(80$ of $88,91 \%)$ than unpaired and unknown status males (66 of $94,70.2 \%)\left(G_{1}=\right.$ $12.9, P=0.001)$. The difference between paired (59 of $78,75.6 \%$ ) and unknown status females ( 22 of $30,73.3 \%)$ was not significant $\left(G_{1}=\right.$ $0.06, P>0.8$ ).

\section{DISCUSSION}

\section{JUVENILE RECRUITMENT}

There was anecdotal evidence that at least some juveniles return to the coast with their mothers, although it is possible that the young birds could have been adopted. The observations show that family-like associations occur far from the nesting area. On the breeding grounds, adult female Harlequin Ducks are often, but not always, found with their fully fledged ducklings just prior to departure (Kuchel 1977, Cassirer and Groves 1994) and the above observation suggests that at least some families travel to the coast together. To our knowledge this is the first indication among migrant Anatinae of broods arriving at the wintering ground, probably accompanied by their mothers, even though it is a common phenomenon in geese (Owen 1980, Prevett and MacInnes 1980). Due to strong winter philopatry (Raveling 1979, Rees 1987), these locations become the permanent wintering locations of these young birds, and therefore locations where mates are eventually chosen. Among dabbling duck species, young are abandoned by their mothers prior to departure to the wintering areas (Nichols and Hines 1987) and it seems unlikely that they migrate to the same wintering grounds as their parents (Robertson and Cooke 1999), but there is little direct evidence either way. Our evidence suggests that some sea-ducks differ in this respect from dabbling ducks.

\section{LOCAL SURVIVAL}

Local survival rates, which provide information on a combination of mortality and permanent emigration (Lebreton et al. 1992), differed considerably among the different sex, age, and breeding status categories of Harlequin Ducks in our sample. Some of these likely reflect differences in true survival, but others relate to tendencies of some classes of birds to emigrate more than others. We have some direct evidence of movement. Two adult males moved from the molting site at WR to the site at PR in successive years. An SY male that had been banded during molt at WR in 1995, spent the whole winter there and failed to find a mate. He left in late April 1996, was shot in the following November near Duluth, Minnesota, way out of normal wintering range of Harlequin Ducks. Apart from this direct evidence, in general we must rely on additional knowledge of survival to infer movement patterns.

Adult males had higher local survival rates than adult females, consistent with the male-biased sex-ratio and lower male mortality in this, and many other, duck species (Bengtson 1972, Sargeant and Raveling 1992). Some of the differences in local survival may reflect differences in true mortality rather than in emigration rates. Adult female mortality was significantly higher than that of adult males during the summer months, suggesting that higher female mortality may be associated with nesting and brood rearing. Both sexes migrate to and from the breeding grounds and are probably subject to similar mortality risk at this time. They also are both in the same locations prior to nesting, but incubation and brood rearing are the sole responsibility of the female. Depredation of females during nesting has been documented in Harlequin Ducks (Brodeur 1997, Bruner 1997). Additionally, over-summer survival is higher in nonbreeding rather than breeding female Mallards (Anas platyrhynchos) (Reynolds et al. 1995), and female survival of Canvasbacks (Aythya valisineria) is high outside the breeding season (Hohman et al. 1993).

In contrast to summer survival, winter survival was similar in the two sexes. Without more information it is difficult to know whether true survival and emigration rates were similar in the two sexes or whether the higher tendency of one sex to emigrate was balanced by higher mortality of the other sex. Winter survival in this study includes the molting period. During the molting period, each bird is usually seen 15 to 30 times (Robertson et al., in press). Only two birds, both males, disappeared during the molt and because they were flightless it was unlikely they emigrated. This evidence suggests that, in at least this species, the molt period is not a time of increased vulnerability to predation, contrary to what several authors have suggested for waterfowl (Panek and Majewski 1990, Hohman et al. 1992). 
Paired males have a high rate of local annual survival (90.9\%), suggesting both a low annual mortality rate and low emigration. Because males show high mate fidelity (Robertson et al. 1998 b, C. M. Smith, unpubl. data) and returned to the molting areas prior to their mates, high site fidelity may provide a mechanism for maintaining the pair bond (Savard 1985, Robertson et al. 1998b). The lower return rate of the unpaired and unknown status males $(70.2 \%)$ could have been due to their status as lower quality individuals. There are quantifiable differences in the quality of male Harlequin Ducks (Robertson et al. 1998a). Whether unpaired birds had a higher mortality rate or a greater tendency to emigrate permanently to other locations is not known, but we suspect that the difference in local survival rate $(90.9-70.2=20.7 \%)$ between paired and other males was too high to be due only to higher mortality. Some unpaired males may have left the area to seek unpaired females, as did the bird that reached Duluth. At WR, most $(87 \%)$ newly banded males were $>3$ years of age. We suspect that this indicates an immigration of unbanded adult males into our study area, again suggestive of some movement of adult males among wintering locations (Robertson et al., in press). The evidence that males have higher local survival rates after they have spent at least one season at the study area was also consistent with an increased emigration of unpaired males. Females did not show this pattern; they had similar local survival rates, regardless of whether they had prior experience with the study area. D. Esler (pers. comm.) found that $92 \%$ of radio-marked adult females molting and wintering in Prince William Sound, Alaska moved less than $20 \mathrm{~km}$.

Survival of younger females was similar to that of adult females. Juvenile females often remained in the wintering location throughout their first summer but older birds left presumably for the breeding grounds. Females pair for the first time in their second or third spring, when they are approximately 21 or 33 months of age (Robertson et al. 1998b) and at least some of them attempt breeding (Reichel et al. 1997). No females attempt pairing or nesting as yearlings. The similarity between survival estimates between younger and older females suggests that young females did not disperse more than adult females. However, an alternate explanation is that younger females have a lower annual mor- tality because they generally do not breed, and that this is balanced by a higher tendency to emigrate.

Younger males had lower local survival rates than females and adult males, and neither of the banded HY males remained in the study area. Some unbanded HY males, detectable in their first alternate plumage (Smith et al. 1998), did occur in our population. Higher mortality of younger males relative to females is an unlikely reason for this lower local survival, given an equal or male-biased sex ratio at fledging (Korschgen et al. 1996, C. Smith, unpubl. data) and an adult sex ratio skewed towards males. Fewer SY and TY males are captured during molt than SY and TY females. If most juvenile birds arrived with their parents, then we would have expected an equal number of HY males and females during their first winter. The lower proportion of SY and TY males suggests that many of the young males emigrated and that there was no equivalent immigration of young males from other locations. Possibly younger males were excluded from wintering areas where breeding males congregate. There is little overt aggression in this species (Gowans et al. 1997), but young males might represent possible rivals to resident males, whereas young females might be accepted in the population. Young males are often seen in peripheral areas not preferred by breeding pairs, but more data are needed to resolve this issue.

\section{POPULATION STRUCTURE}

Pair formation in Harlequin Ducks occurs in the winter (Robertson et al. 1998b) and the degree of relatedness of potential mates depends on the probability of relatives of the opposite sex being at the same wintering area. There was some indication that young birds originally located in the same wintering area as their parents. Our data suggested that many of the young males and some unpaired adult males dispersed, indicating that there is a considerable amount of gene flow among populations mediated by the dispersal of young and unpaired adult males. Lanctot et al. (1999) provide genetic validation for our conclusions from different Harlequin Duck populations in Alaska. Given this sex-biased dispersal, one might predict differences in mtDNA allele frequencies in contrast to nuclear DNA. This pattern of winter philopatry, with males dispersing more than females, is similar 
to the breeding philopatry patterns of other waterfowl (Cooke et al. 1975, Rohwer and Anderson 1988, Anderson et al. 1992).

The pattern of winter population structure in species which choose their mates away from the breeding locations will influence the population structure in the breeding areas. Those species showing little or no population structure in the winter would not be expected to show genetic differentiation during the breeding season. But even those species which might show strong genetic differentiation during the winter, may not necessarily breed in genetically differentiated populations. The relationship between the genetic structure on the one hand, and breeding and wintering locations on the other, is much more complex in species which form pairs away from the breeding location than it is for those which pair where they breed. This complexity needs to be recognized before detailed studies of the genetic structure of wintering and breeding populations are undertaken (Ely and Scribner 1994).

\section{ACKNOWLEDGMENTS}

We thank all of the many people who assisted us in capturing and observing molting Harlequin Ducks. Various aspects of this study have received funding from the British Columbia Waterfowl Society, the Institute for Wetland and Waterfowl Research, the Natural Sciences and Engineering Research Council of Canada (NSERC), the Pacific and Yukon Region or the Canadian Wildlife Service (CWS), the CWS/ NSERC Wildlife Ecology Research Chair, and Simon Fraser University.

\section{LITERATURE CITED}

Anderson, M. G., J. M. Rhymer, And F. C. Rohwer. 1992. Philopatry, dispersal and the genetic struc ture of waterfowl populations, p. 365-395. In B. D. J. Batt, A. D. Afton, C. D. Ankney, D. H. Johnson, J. A. Kadlec, and G. L. Krapu [EDS.], Ecology and management of breeding waterfowl. Univ. Minnesota Press, Minneapolis, MN.

Ankney, C. D., D. G. Dennis, L. N. Wishard, AND J. E. SeEb. 1986. Low genic variation in Black Ducks and Mallards. Auk 103:701-709.

$\rightarrow$ Bengtson, S.-A. 1972. Breeding ecology of the Harlequin Duck (Histrionicus histrionicus) in Iceland. Ornis Scand. 3:1-19.

Breault, A. M., and J-P. L. Savard. 1991. Status report on the distribution and ecology of Harlequin Ducks in British Columbia. Can. Wildl. Serv., Tech. Rep. Ser. No. 110. Pacific and Yukon Region, Delta, British Columbia, Canada..

Breault, A. M., and J-P. L. SAvard. In press. Philopatry of Harlequin Ducks moulting in souther British Columbia. In R. I. Goudie, M. R. Petersen, and G. J. Robertson [EDS.], Behaviour and ecology of the sea ducks. Can. Wildl. Serv. Occ. Pap., Ottawa.

Brodeur, S. 1997. Étude des deplacements du canard arlequin (Histrionicus histrionicus) á l'aide de radio-émetteurs. Prepared for Travaux Publics et Services Gourvernmentaux Canada, Bromont, Québec.

Brown, M. E. 1998. Population genetic structure, philopatry and social structure in three Harlequin Duck (Histrionicus histrionicus) breeding subpopulations. M.Sc. thesis, Univ. California, Davis, CA.

BRUNER, H. 1997. Habitat use and productivity in the central Cascade Range of Oregon. M.Sc. thesis, Oregon State Univ., Corvallis, OR.

Cassirer, E. F., and C. R Groves. 1994. Ecology of Harlequin Ducks in Northern Idaho. Idaho Dept. Fish and Game, Boise, ID.

Cooke, F., C. D. MacInnes, and J. P. Prevett. 1975. Gene flow between breeding populations of Lesser Snow Geese. Auk 92:493-510.

Cooke, F., G. J. Robertson, R. I. Goudie, ANd W. S. BoyD. 1997. Molt and the basic plumage of male Harlequin Ducks. Condor 99:83-90.

Cronin, M. A., J. B. Grand, D. Esler, D. V. Derksen, AND K. T. SCRIBNER. 1996. Breeding populations of Northern Pintails have similar mitochondrial DNA. Can. J. Zool. 74:992-999.

Dow, H., AND S. Fredga. 1983. Breeding and natal dispersal of the Goldeneye, Bucephala clangula. J. Anim. Ecol. 53:679-692.

Ely, C. R., AND K. T. SCRIBNER. 1994. Genetic diversity in arctic-nesting geese: implications for management and conservation. Trans. N. Am. Wildl. Nat. Res. Conf. 59:91-110.

Fedynich, A. M., R. D. Godfrey JR., AND E. G. BolEN. 1989. Homing of anatids during the nonbreeding season to the southern high plains. J. Wildl. Manage. 53:1104-1110.

Gowans, B., G. J. Robertson, And F. CoOKe. 1997. Behaviour and chronology of pair formation by Harlequin Ducks Histrionicus histrionicus. Wildfowl 48:135-146.

Greenwood, P. J. 1980. Mating systems, philopatry and dispersal in birds and mammals. Anim. Behav. 28:1140-1162.

Hohman, W. L., C. D. Ankney, and D. H. Gordon. 1992. Ecology and management of postbreeding waterfowl, p. 128-189. In B. D. J. Batt, A. D. Afton, C. D. Ankney, D. H. Johnson, J. A. Kadlec, and G. L. Krapu [EDS.], Ecology and management of breeding waterfowl. Univ. Minnesota Press, Minneapolis MN.

Hohman, W. L., R. D. Pritchart, J. L. Moore, and D. O. SCHAEFfer. 1993. Survival of female Canvasbacks wintering in coastal Louisiana. J. Wildl. Manage. 57:758-762.

Johnson, M. L., AND M. S. Gaines. 1990. Evolution of dispersal: theoretical models and empirical tests using birds and mammals. Annu. Rev. Ecol. Syst. 21:448-480.

Korschgen, C. E., K. P. Kenow, W. L. Green, D. H. Johnson, M. D. SAmuel, ANd L. Sileo. 1996. Sur- 
vival of radiomarked Canvasback ducklings in northwestern Minnesota. J. Wildl. Manage. 60: 120-132.

KuCHEL, C. R. 1977. Some aspects of the behavior and ecology of Harlequin Ducks breeding in Glacier National Park, Montana. M.Sc. thesis, Univ. Montana, Missoula, MT.

Lanctot, R., B. Goatcher, K. Scribner, S. Talbot, B. Pierson, D. Esler, AND D. Zwiefelhofer. 1999. Harlequin Duck recovery from the Exxon Valdez oil spill: a population genetics perspective. Auk 116, in press.

Lebreton, J.-D., K. P. Burnham, J. Clobert, and D. R. ANDERSON. 1992. Modeling survival and testing biological hypotheses using marked animals: a unified approach with case studies. Ecol. Monogr. 62:67-118.

MATHER, D. D., AND D. Esler. 1999. Evaluation of bursal depth as an indicator of age class of Harlequin Ducks. J. Field Ornithol. 70, in press.

Nichols, J. D., AND J. E. HinES. 1987. Population ecology of the Mallard. VIII. Winter distribution and survival rates of winter-banded Mallards. U.S. Dept. Interior Fish Wildl. Serv., Resource Publ. No. 162, Washington, DC.

PANEK, M., AND P. MAJEWSKI. 1990. Remex growth and body mass of Mallards during wing molt. Auk 107:255-259.

Pollock, K. P., J. D. Nichols, C. Brownie, AND J. E. HiNES. 1990. Statistical inference for capture-recapture experiments. Wildl. Monogr. 107:1-97.

Prevett, J. P., And C. D. MacInNEs. 1980. Family and other social groups in Snow Geese. Wildl. Monogr. 71:1-46.

Raveling, D. G. 1979. Traditional use of migration and winter roost sites by Canada Geese. J. Wildl. Manage. 43:229-235.

REES, E. C. 1987. Conflict of choice within pairs of Bewick's Swans regarding their migratory movement to and from the wintering grounds. Anim. Behav. 35:1685-1693.

Reichel, J. D., D. L. Genter, AND D. P. Hendricks. 1997. Harlequin Duck research and monitoring in Montana: 1996. Montana Natural Heritage Program, Helena, MT.

Reynolds R. E., R. J. Blohm, J. D. Nichols, AND J. E. HINES. 1995. Spring-summer survival rates of yearling versus adult Mallard females. J. Wildl. Manage. 59:691-696.

Robertson, G. J., AND F. COOKE. 1999. Winter philopatry in migratory waterfowl. Auk 116:20-34.

Robertson, G. J., F. COOKe, R. I. Goudie, AND W. S. BOYD. 1997a. Estimating temporary emigration rates with supplementary information: an example with Harlequin Ducks. Ring 19:169-178.
Robertson, G. J., F. Cooke, R. I. Goudie, And W. S. BoYD. 1997b. The timing of arrival and moult chronology of Harlequin Ducks Histrionicus histrionicus. Wildfowl 48:147-155.

Robertson, G. J., F. CoOke, R. I. Goudie, And W. S. BOYD. 1998a. Moult speed predicts pairing success in male Harlequin Ducks. Anim. Behav. 55: 1677-1684.

Robertson, G. J., F. CoOKe, R. I. Goudie, And W. S. BOYD. 1998b. The timing of pair formation in Harlequin Ducks. Condor 100:551-555.

Robertson, G. J., F. COOKE, R. I. Goudie, AND W. S. BoYD. In press. Within-year fidelity of Harlequin Ducks to moulting and wintering area. In $\mathrm{R}$. I. Goudie, M. R. Petersen, and G. J. Robertson [EDS.], Behaviour and ecology of sea ducks. Can. Wildl. Serv. Occ. Pap. 100, Ottawa.

Rockwell, R. F., AND G. F. BARROWCLOUGH. 1987. Gene flow and the genetic structure of populations, p. 223-235. In F. Cooke and P. A. Buckley [EDS.], Avian genetics. Academic Press, London.

Rohwer, F. C., AND M. G. ANDERSON. 1988. Femalebiased philopatry, monogamy, and the timing of pair formation in migratory waterfowl. Current Ornithol. 5:187-221.

Sargeant, A. B., AND D. G. Raveling. 1992. Mortality during the breeding season, p. 396-422. In B. D. J. Batt, A. D. Afton, C. D. Ankney, D. H. Johnson, J. A. Kadlec, and G. L. Krapu [EDS.], Ecology and management of breeding waterfowl. Univ. Minnesota Press, Minneapolis, MN.

SAVARD, J.-P. L. 1985. Evidence of long-term pair bonds in Barrow's Goldeneye (Bucephala islandica). Auk 102:389-391.

SAVARD, J.-P. L. AND J. M. EAdIE. 1989. Survival and breeding philopatry in Barrow's and Common Goldeneyes. Condor 91:198-203.

Smith, C. M., F. Cooke, And R. I Goudie. 1998. Ageing Harlequin Duck (Histrionicus histrionicus) drakes using plumage characteristics. Wildfowl 49:245-248.

Smith, C. M., F. Cooke, G. J. Robertson, R. I. GouDIE, AND W. S. BOYD. 2000. Long-term pair bonds in Harlequin Ducks. Condor 102:201-205

Syroechkovsky, E. V., F. Cooke, AND W. J. L. SLAdEN. 1994. Population structure of the Lesser Snow Geese of Wrangel Island, Russia. EcoScience 1: 311-316.

White, G. C., and K. P. Burnham. 1999. Program MARK: survival estimation from populations of marked animals. Bird Study (supplement):120139.

Witherby, H. F., F. C. R. Jourdain, N. F. Ticehurst, AND B. W. TUCKER. 1943. The handbook of British birds. Vol. III. H. F. and G. Witherby, London. 